\title{
Compaction as a sustainable alternative to dried sludge from poultry slaughterhouse wastewater for energy generation
}

\section{Julio Peretti da Silva ${ }^{*}$ (D) Martha Andreia Brand ${ }^{2}$ (D) Philipe Ricardo Casemiro Soares ${ }^{2}$ (iD Matheus de Liz Salamon' (iD) Taíse Mariano Rodrigues' ${ }^{1}$ (D) Germano Güttler ${ }^{3}$ (D)}

'Programa de Pós-graduação em Engenharia Florestal, Universidade do Estado de Santa Catarina (UDESC), 88520-000, Lages, SC, Brasil. E-mail: icoperetti@hotmail.com. "Corresponding author.

${ }^{2}$ Departamento de Engenharia Florestal, Universidade do Estado de Santa Catarina (UDESC), Lages, SC, Brasil.

${ }^{3}$ Departamento de Agronomia, Universidade do Estado de Santa Catarina (UDESC), Lages, SC, Brasil.

\begin{abstract}
The generation of wastes in poultry abattoirs has increased considerably in recent years due to the growing demand for chicken meat. This fact, combined with the current need for developing new forms of renewable energy from biomass, and the lack of disposal facilities, motivated this study. We determined the technical feasibility of the barbecue charcoal production using briquettes produced with different blends containing sludge from a poultry abattoir and Pinus spp. shavings. To that end, we have mixed both residues by gradually adding 10 to $90 \%$ of sludge in the blends, which resulted in 9 treatments containing sludge, and 1 containing only shavings. After that, we produced four briquettes of each treatment and charred them by using a heating ramp. After charring, we submitted the charcoal to the analyzes of Moisture Content (MC), Bulk Density (BD), Compressive Resistance (CR), Gross Calorific Value (GCV), and Proximate Analysis (PA). We calculated the Gravimetric Yield (GY) and the Energy Density (ED) by using the results from the other analyzes. Results showed that the CR, the GCV, the Volatile Matter (VM), and the Fixed Carbon Content $(F C)$ of the charcoals decreased by increasing the proportion of sludge in the blends. However, the charcoals' bulk density (BD) increased, which also increased its energy density (ED) and ash content (AC). The best blend to produce charcoal for household use was the one containing $90 \%$ of sludge and $10 \%$ of Pinus spp. shavings.
\end{abstract}

Key words: barbecue charcoal, renewable energy, briquettes.

Compactação como uma alternativa de uso sustentável do efluente flotado de abatedouro de aves para geração de energia

RESUMO: A geração de efluentes nos abatedouros de aves aumentou consideravelmente nos últimos anos devido à crescente demanda por carne de frango. Esse fato, combinado com a atual necessidade de desenvolvimento de novas formas de energia renovável a partir da biomassa e a falta de instalações de descarte para isso, motivou este estudo. O objetivo foi determinar a viabilidade técnica da produção de carvão para churrasco, usando briquetes produzidos com diferentes misturas contendo lodo de abatedouro de aves e maravalha de Pinus spp. Para determinar a viabilidade técnica, misturou-se os dois resíduos adicionando gradualmente 10-90\% de lodo nas misturas, o que resultou em nove tratamentos contendo lodo e um contendo apenas maravalha. Depois disso, quatro briquetes de cada tratamento foram produzidos e carbonizados. Após a carbonização, os carvões foram submetidos às análises de teor de umidade (MC), densidade a granel (BD), resistência à compressão (CS), poder calorifico superior (GCV) e análise imediata (PA). O Rendimento Gravimétrico (GY) e a Densidade Energética (DE) de cada tratamento foram calculados usando os resultados das outras análises. A resistência à compressão (CR), o poder calorífico superior $(G C V)$, o teor de voláteis $(V M)$ e o teor de carbono fixo (FC) do carvão diminuiu com o aumento da proporção de lodo nas misturas. A densidade aparente (BD), o teor de cinzas $(A C)$ e a densidade energética (ED) aumentaram com o acréscimo de lodo na mistura. A melhor mistura para a produção de carvão de briquetes para uso doméstico foi a que teve $90 \%$ de lodo e $10 \%$ de partículas de Pinus.

Palavras-chave: carvão para churrasco, energia renovável, briquetes.

\section{INTRODUCTION}

Brazil is a huge generator of organic wastes considering its population. It has abundant food and fuel production, animal growing, and several production processes that eliminate by-products that companies could exploit in different ways (DE LUCAS \& SANTOS, 2016).
The production of chicken meat in Brazil has increased lately. According to the ABPA's 2019 annual report (Brazilian Association of Animal Protein), Brazil produced 12.86 million tons of chicken meat in 2018, which makes the country the second-largest producer in the world (ABPA, 2019). In this sense, it is common knowledge that the growth in the number of poultry slaughterhouses has caused 
an increase in the generation of effluents from them, which are highly pollutants and can, if inadequately disposed of, cause serious environmental problems.

The wastewater from poultry abattoirs contains blood, viscera, excrement, fats, substances contained in the digestive tract of animals, among others, characterizing an effluent with high organic matter concentration (BEUX, 2005). These effluents require active treatment, and one of the processes used as a treatment is the coagulation followed by flotation, which aims to increase the efficiency of removing organic matter, oils, and greases from the water. This process generates a large amount of residual sludge that needs to undergo treatment and eliminated appropriately (GARCIA, 2016; PINTO et al., 2018). According to GARCIA (2016), the companies generally intend this sludge for disposal or landfill, which culminates in the generation of undesirable residues such as slurry and methane (CH4), polluting the water, the air, and the soil.

The floated sludge is the substantial portion of the effluent, containing nearly $60 \%$ of moisture content, and it has inherent characteristics to be used as fuel. UNFRIED \& YOSHI (2012) recommend the drying of the sludge "cake" as it favors its energy use by direct combustion. In this way, this material must undergo a drying process to reduce its moisture content to a range between 12 and $15 \%$.

Moreover, this dried sludge characterizes itself as an environmental problem because it does not decompose in nature. TOLMASQUIM (2005) stated that there has been a growing interest in new energy production alternatives from biomass due to the increase in the number of agriculture residues along with the need for disposing of them correctly and with economical use. Also, the world has raised social pressures for clean sources of energy which do not emit greenhouse gases in the last few years.

The United Nations Development Program (PNUD) launched the Sustainable Development Agenda 2030 with the 17 Sustainable Development Goals (SDG) in December 2015 (PNUD, 2015). PNUD's goal number 7 is directly related to energy: "Ensuring reliable, sustainable, modern, and affordable access to energy for all". It focuses on renewable energy, energy efficiency, international cooperation in research and clean energy technologies, clean energy infrastructure, and modern and sustainable energy services for all developing countries.

In Brazil, the National Solid Waste Policy (PNRS) (Law 12,305 of 2010 and Decree No. 7.404 of December 23, 2010, which regulates Law No. 12,305) in its Article 7, also mentions the use of energy as a practice to be encouraged in companies. (BRAZIL, 2010).

Companies can recover the organic wastes of several processes in the form of renewable energy. Many of them can be used in the same production place, which decentralizes energy production, minimizes the logistics, and creates the possibility of energy self-sufficiency for several producers. Renewable energy production contributes to the increase of the world energy matrix, the reduction of inadequate disposals in the environment, the generation of business opportunities, and more significant social and economic development (DE LUCAS \& SANTOS, 2016).

One of the ways to turn biomass into energy is through its compaction or densification. GRANADA et al. (2002) mentioned that biomass briquetting is a densification process that improves the characteristics of the residual biomass, i.e., it increases energy density, reduces transportation costs, and produces a uniform fuel.

Having that in mind, the commercialization of briquettes is still not widespread in Brazil. Therefore, an alternative for the briquette produced with the sludge from poultry abattoirs and Pinus spp. shavings is to char the briquettes in order to produce charcoal.

PRINS et al. (2006) stated that roasting and charring briquettes may be alternatives to improve their quality and commercialization since biomass thermal treatments result in increased energy density and decreased moisture content. Besides, the process converts briquettes into fuel with higher gross calorific value, lower volatile content, higher fixed carbon content, uniformity in shape and size, lower $\mathrm{O} / \mathrm{C}$ ratio, and low humidity (PRINS et al., 2006).

The final destination of the charcoal produced in Brazil is varied. According to the National Energy Balance (BEN) of 2016, the country consumed about 870 thousand tons in homes and small commercial applications, which represents $0.14 \%$ of the country's total production (BRAZIL, 2016). Barbecue charcoal features a large and robust charcoal market niche. According to BRAND et al. (2015), the use of charcoal in industries for energy purposes is not significant in South Brazil. However, when it comes to domestic use, its application stands out for the preparation of barbecue, considering that this food has great cultural importance for the population of the Southern States.

In this sense, this study determined the technical feasibility of the production of barbecue charcoal by using briquettes incorporating different blends of sludge from poultry abattoirs wastewater and Pinus spp. shavings. 


\section{MATERIALS AND METHODS}

The poultry waste used in this research is the floated sludge after the drying process. Therefore, it is going to be mentioned here as only sludge. We seek to evaluate the technical feasibility of using this sludge for energy production in the form of charcoal. To that end, the sludge needs to be mixed with lignocellulosic biomass and densified into briquettes. The lignin and cellulose from wood materials improve the densification as they are well-known for their binding characteristics in this process. Because of the well-known quality of Pinus spp. shavings, we have chosen this lignocellulosic material for this research, and we are going to mention it as only shavings.

The residues are from different sources. We collected the Pinus spp. shavings at a company that manufactures doors, and the sludge from poultry abattoirs at a solid-waste treatment company, which works with composting and production of organic fertilizers. Both companies are in Lages, Santa Catarina, Brazil.

Figure 1 shows a general flowchart of the technical feasibility analysis. It covers the structural and energy quality analyzes that have been carried out in this research. We produced the briquettes using blends made with different proportions of sludge and Pinus spp. shavings, which featured the treatments (T1 to T10).

The blends had been conditioned in an air-conditioned room until the stabilization of the moisture content. The briquetting has been carried out by a pilot hydraulic piston briquette machine. We produced a total of 4 briquettes of each treatment presented in figure 1.

First, we heated the briquette machine to the test temperature of approximately $90{ }^{\circ} \mathrm{C}$. Then, we weighed $40 \mathrm{~g}$ of samples containing the residues in different proportions for briquette production. The process duration was 12 minutes, the pressure applied during the first 10 minutes was $5 \mathrm{MPa}$, and during the remaining 2 minutes was $12 \mathrm{MPa}$ (Furtado et al., 2010). The final size of the produced briquettes was $35 \mathrm{~mm}$ in diameter, and they presented varied lengths.

Finally, the carbonization procedure has been carried out in a laboratory. Four briquettes of each treatment have been weighed and measured

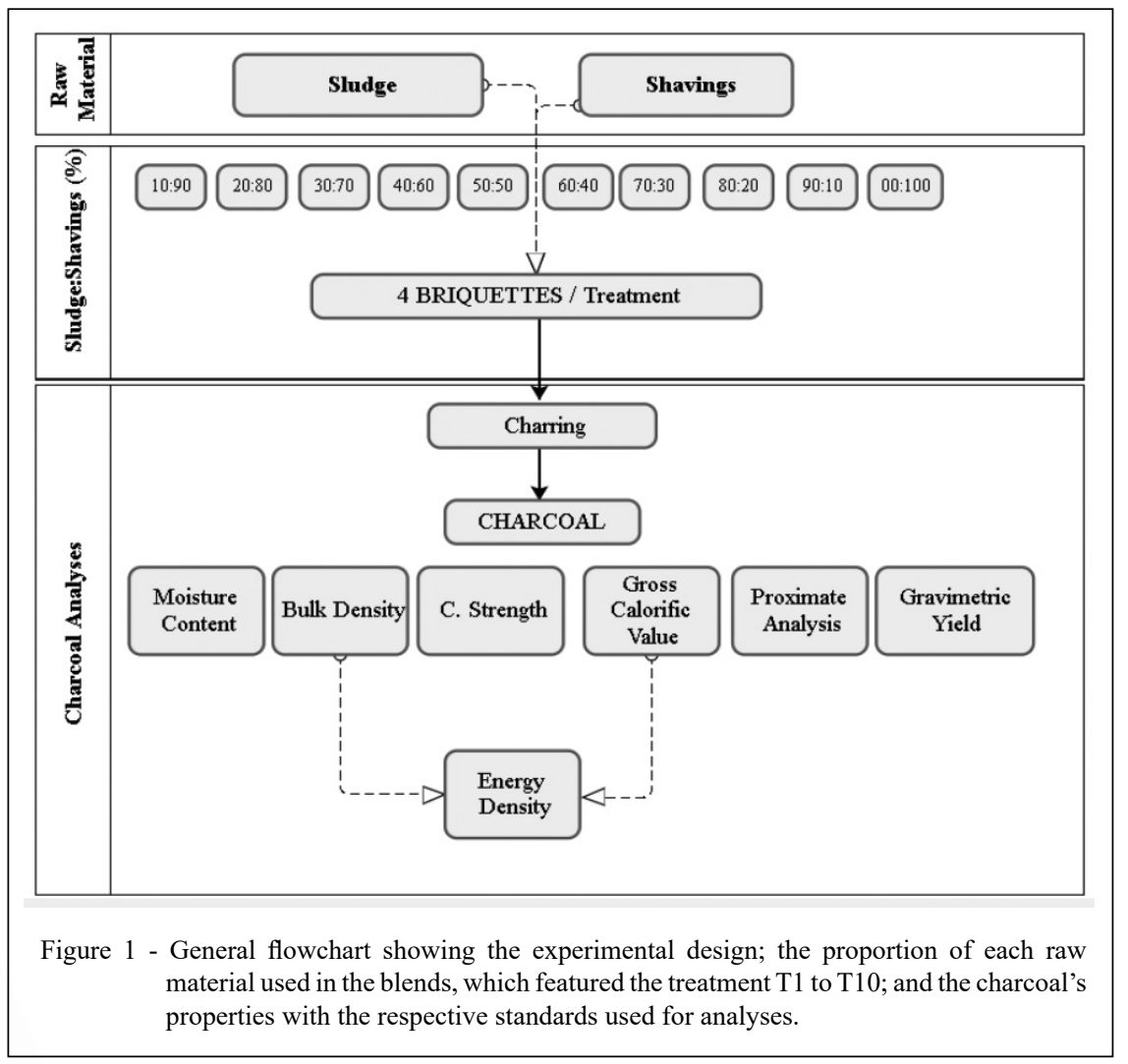

Ciência Rural, v.51, n.12, 2021. 
before charring in order to determine the charcoal's bulk density (BD). The briquettes were wrapped with aluminum foil, identified, and placed in a muffle for charring. The carbonization process was carried out according to a heating ramp. The initial temperature was $50{ }^{\circ} \mathrm{C}$, and it was increased by $50{ }^{\circ} \mathrm{C}$ every 30 minutes until the temperature reached $450{ }^{\circ} \mathrm{C}$ after 4 hours and 30 minutes.

Analyzes of the physical and energetic properties of the charcoal have been carried out according to specific standards (Figure 1). The Energy Density (ED) was calculated by the product of the Gross Calorific Value (GCV) and the Bulk Density (BD).

After charring and cooling, the briquette charcoals were weighed and measured again to determine the Gravimetric Yield (GY). According to NONES et al. (2014), the gravimetric yield is the relation between the final weight of the charcoal and the dry weight of the raw material (pre-carbonization), expressed as a percentage.

The Compressive Strength (CS) is the maximum amount of weight that a briquette or charcoal can withstand before cracking or breaking. We performed the CS test according to what was stated by BRAND et al. (2017). We loaded the charcoal between two flat and parallel presses with facial areas more extensive than the projected area of the charcoal. An increasing load was applied at a constant rate $\left(2 \mathrm{~mm} \mathrm{~min}^{-1}\right)$ until the test body cracked or broke. The fracture load was read by a pressure overload curve, which is the compressive strength reported as force or stress. Then, we determined the compressive strength of the samples by the diametric compression test.

The maximum load was calculated using equation 1 .

$C=\frac{2 x F}{\pi x d x l}$

In which: $\mathrm{C}=$ cracking or breaking maximum load $(\mathrm{MPa}) ; \mathrm{F}=$ strength in Newton $(\mathrm{N}) ; \mathrm{d}$ $=$ diameter $(\mathrm{mm}) ; 1=$ length $(\mathrm{mm})$, where $\pi$ is 3.1416 .

Regarding the descriptive statistics of the data, we obtained the averages and coefficients of variation and submitted all variables to statistical analysis using the software SISVAR and the ScottKnott Test at $5 \%$ of significance. In order to assess the relationship between de Energy Density (ED) and the Gross Calorific Value (GCV) and the Energy Density (ED) and the Bulk Density (BD), we have calculated the Pearson correlation coefficient.

\section{RESULTS AND DISCUSSION}

Results regarding the physical and mechanical characteristics of the charcoal (Table 1) showed that the different blends influenced the charcoal's moisture content (MC) but without showing a pattern among treatments. However, there was a variation between treatments. According to the São Paulo Premium Seal (SÃO PAULO, 2015), which is a quality seal for charcoal produced in the state of São Paulo without

Table 1 - Physical and mechanical properties of the briquette charcoal and statistical analysis.

\begin{tabular}{|c|c|c|c|c|}
\hline Treatment & MC (\%) & $\mathrm{CR}(\mathrm{MPa})$ & $\mathrm{BD}\left(\mathrm{g} \cdot \mathrm{cm}^{-3}\right)$ & GY (\%) \\
\hline $\mathrm{T} 1$ & $6.34 \mathrm{a}$ & $0.60 \mathrm{a}$ & $0.663 \mathrm{c}$ & $34.54 \mathrm{~b}$ \\
\hline $\mathrm{T} 2$ & $5.63 \mathrm{~b}$ & $0.57 \mathrm{a}$ & $0.675 \mathrm{c}$ & $34.76 \mathrm{~b}$ \\
\hline $\mathrm{T} 3$ & $6.01 \mathrm{~b}$ & $0.60 \mathrm{a}$ & $0.693 \mathrm{c}$ & $34.56 \mathrm{~b}$ \\
\hline $\mathrm{T} 4$ & $5.10 \mathrm{c}$ & $0.39 \mathrm{~b}$ & $0.673 \mathrm{c}$ & $34.62 \mathrm{~b}$ \\
\hline T5 & $6.37 \mathrm{a}$ & $0.44 \mathrm{~b}$ & $0.695 \mathrm{c}$ & $34.11 \mathrm{c}$ \\
\hline T6 & $6.94 \mathrm{a}$ & $0.22 \mathrm{c}$ & $0.695 \mathrm{c}$ & $34.18 \mathrm{c}$ \\
\hline $\mathrm{T} 7$ & $5.65 \mathrm{~b}$ & $0.17 \mathrm{c}$ & $0.690 \mathrm{c}$ & $35.58 \mathrm{a}$ \\
\hline $\mathrm{T} 8$ & $4.74 \mathrm{c}$ & $0.22 \mathrm{c}$ & $0.765 \mathrm{~b}$ & $34.88 \mathrm{~b}$ \\
\hline T9 & $4.62 \mathrm{c}$ & $0.22 \mathrm{c}$ & $0.815 \mathrm{a}$ & $33.36 \mathrm{c}$ \\
\hline $\mathrm{T} 10$ & $5.90 \mathrm{~b}$ & $0.48 \mathrm{~b}$ & $0.683 \mathrm{c}$ & $33.66 \mathrm{c}$ \\
\hline CV (\%) & 7.44 & 26,86 & 2.79 & 1.45 \\
\hline Average & 5.73 & 0.391 & 0.705 & 34.43 \\
\hline
\end{tabular}

Means followed by equal letters (vertical) do not differ statistically from each other by the Tukey test at $5 \%$. Note: MC $=$ Moisture Content; $\mathrm{CR}=$ Compressive Resistance; $\mathrm{BD}=$ Bulk Density; GY= Gravimetric Yield; CV= Coefficient of Variation. 
the use of child labor and in accordance with some environmental standards, the moisture content of household charcoal must be up to $5 \%$. Thus, only the T8 and T9 treatments would meet this barbecue charcoal quality criterion.

The effect of mixing the residues for briquette production was significant for the compressive resistance (CR). The increase in the amount of sludge contributed considerably to the reduction of the charcoal's CR. Briquettes produced with 10,20 , and $30 \%$ of sludge had similar CRs, and higher than the other treatments. The ones produced with 40 to $50 \%$ formed an intermediate CR group, and briquettes with 60 to $90 \%$ of sludge generated the charcoals with the lowest CRs. Treatments T4 and T5 presented the same quality as T10, which contains only Pinus spp. shavings.

SANTOS (2008) claimed that CR is an essential feature of the charcoal used in the steel industry. However, for household use, it relates only to the number of fines generated during transport and the allowed weight above in storage. As the average CR was $0.391 \mathrm{MPa}$, which is around $6,110 \mathrm{~kg} \cdot \mathrm{m}^{-2}$, we can say that each charcoal's square meter can support $6,110 \mathrm{~kg}$ above without breaking. Although, the CR values reported in the literature are higher than the ones found in this study (e.g., VEIGA et al. (2006), 7,32 a $15,69 \mathrm{MPa}$ for Eucalyptus charcoal), this is enough considering the household application.

The amount of sludge in the blends influenced the charcoal's bulk density (BD) in an opposite way. The increase in the amount of sludge caused the charcoal's BD to increase. The charcoals produced with 10 to $70 \%$ of sludge had BDs of 663 to $695 \mathrm{~kg} \cdot \mathrm{m}^{-3}$. The $10 \%$ increase of sludge in the composition of the briquettes led to an increase of at least $70 \mathrm{~kg}$ for each cubic meter of charcoal with $80 \%$ of sludge. Moreover, adding $10 \%$ of sludge into the blend increased an additional $50 \mathrm{~kg}$ per cubic meter of the charcoals produced with $90 \%$ of sludge.

The increase of the charcoal's BD with the inclusion of the sludge, mainly with 80 and 90 $\%$, can be explained by the particle size differences between the sludge and the shavings. As the sludge presents smaller particles, the increase in the amount of sludge increases the mass per volume unit, which allows the particles to compact better and form a denser briquette.

Wood charcoal's BD is often lower than the one reported in this study. BRAND et al. (2015) presented BDs around $0.403 \mathrm{~g} / \mathrm{cm}^{3}$ when studying the leading brands of household wood charcoal marketed in South Brazil. Similarly, PROTÁSIO et al. (2013) found BDs varying from 0.220 to $0.440 \mathrm{~g} / \mathrm{cm}^{3}$ when studying Eucalyptus spp. clones used for charcoal production. The gravimetric yield (GY) was different between treatments. T7 was the best, presenting the highest GY, followed by treatments T8, T1, T2, T3, and T4. Although, the results did not explain the influence of the different mixing proportions on the charcoal's GY, they are similar to the ones reported in the literature for wood charcoal (e.g., PROTÁSIO et al., 2013, GY = $32.02 \%$; BOTREL et al., 2007, GY $=35.03 \%$ ).

Regarding the chemical and energetic analysis, the results showed that the different blends influence the charcoal's proximate analysis (Table 2). The increase in the amount of sludge in the blends decreased the volatile matter (VM), which is good, and the fixed carbon content (FC) of the charcoal. The lowest and; therefore, the best VMs were the ones from treatments T9, T8, T7, T6, and T5, which were all statistically similar to each other. These values were lower than the one obtained from T10, which is produced only with Pinus spp. shavings. As the sludge is composed of mainly animal organic matter, the T9 may have presented the lowest VM because the combustion process released most of the volatiles.

The charcoal's VM was excellent and close to the VM of wood charcoal. BRAND et al. (2015) reported a mean VM of $32.85 \%$ in wood charcoal for household use of brands marketed in South Brazil. Similarly, OLIVEIRA et al. (2015) presented VMs varying from 14.53 to $40.70 \%$ when studying wood charcoal for household use in Paraná, South Brazil.

Treatments T1, T2, and T3, showed the best fixed-carbon contents (FC), being only lower than T10. Brazil lacks studies regarding the quality of the marketed household charcoal. The state of São Paulo is the only one which has a Premium Seal, therefore, we used it for comparison only as it does not represent the reality of Brazil. The São Paulo Premium Seal (SÃO PAULO, 2015) demands an FC above $73 \%$, which would exclude all treatments from household use. However, not even the charcoal produced only with wood shavings presented an FC higher than $73 \%$. Moreover, BRAND et al. (2015) claimed that the leading brands marketed in South Brazil sell household charcoal with FCs of $65.17 \%$, which is similar to the ones reported in this study.

Nevertheless, the charcoal's ash content (AC) presented an inverse behavior. Adding $10 \%$ more sludge to the blends caused each treatment to be statistically different from each other. The AC was the property that was most influenced by the amount of sludge in the blends, and all the treatments would not 
Table 2 - Chemical and energetic properties of the briquette charcoal with the statistical analysis.

\begin{tabular}{|c|c|c|c|c|c|}
\hline Treatment & VM (\%) & $\mathrm{FC}(\%)$ & $\mathrm{AC}(\%)$ & GCV (MJ.kg $\left.{ }^{-1}\right)$ & $\mathrm{ED}\left(\mathrm{GJ} . \mathrm{m}^{-3}\right)$ \\
\hline $\mathrm{T} 1$ & $30.34 \mathrm{a}$ & $66.21 \mathrm{~b}$ & $3.45 \mathrm{i}$ & $29.138 \mathrm{~b}$ & $19.38 \mathrm{~b}$ \\
\hline $\mathrm{T} 2$ & $29.62 \mathrm{a}$ & $64.09 \mathrm{c}$ & $6.28 \mathrm{~h}$ & $28.301 \mathrm{c}$ & $19.05 \mathrm{~b}$ \\
\hline $\mathrm{T} 3$ & $28.33 \mathrm{~b}$ & $62.93 \mathrm{c}$ & $8.75 \mathrm{~g}$ & $28.020 \mathrm{c}$ & $19.31 \mathrm{~b}$ \\
\hline $\mathrm{T} 4$ & $28.27 \mathrm{~b}$ & $61.77 \mathrm{~d}$ & $9.97 \mathrm{f}$ & $27.466 \mathrm{~d}$ & $18.54 \mathrm{c}$ \\
\hline T5 & $26.83 \mathrm{c}$ & $61.37 \mathrm{~d}$ & $11.80 \mathrm{e}$ & $26.482 \mathrm{e}$ & $18.41 \mathrm{c}$ \\
\hline T6 & $26.52 \mathrm{c}$ & $59.12 \mathrm{e}$ & $14.35 \mathrm{~d}$ & $25.702 \mathrm{f}$ & $17.86 \mathrm{~d}$ \\
\hline $\mathrm{T} 7$ & $27.00 \mathrm{c}$ & $56.58 \mathrm{f}$ & $16.42 \mathrm{c}$ & $24.795 \mathrm{~g}$ & $17.12 \mathrm{~d}$ \\
\hline T8 & $26.80 \mathrm{c}$ & $54.07 \mathrm{~g}$ & $19.01 \mathrm{~b}$ & $24.398 \mathrm{~h}$ & $18.65 \mathrm{c}$ \\
\hline T9 & $26.24 \mathrm{c}$ & $51.83 \mathrm{~h}$ & $22.07 \mathrm{a}$ & $23.714 \mathrm{i}$ & $19.30 \mathrm{~b}$ \\
\hline $\mathrm{T} 10$ & $28.65 \mathrm{~b}$ & $70.07 \mathrm{a}$ & $1.20 \mathrm{j}$ & $30.086 \mathrm{a}$ & $20.52 \mathrm{a}$ \\
\hline CV (\%) & 2.20 & 1.14 & 2.63 & 0.9 & 2.94 \\
\hline Average & 27.86 & 60.80 & 11.33 & 26.81 & 18.81 \\
\hline
\end{tabular}

Means followed by equal letters (vertical) do not differ statistically from each other by the Tukey test at $5 \%$. Note: VM $=$ Volatiles matter; $\mathrm{FC}=$ Fixed Carbon; $\mathrm{AC}=$ Ash Content; GCV $=$ Gross Calorific Value; $\mathrm{ED}=$ Energy Density; $\mathrm{CV}=\mathrm{Coefficient}$ of Variation.

be fit for household use according to the São Paulo Premium Seal (SÃO PAULO, 2015). The high AC of the sludge is due to its mineral composition, which can represent from $1.04 \%$ in feather to $24.93 \%$ in digestive tract of animals (NASCIMENTO et al., 2002). Although, the high AC can be a problem in the furnaces of steel industries, it would only represent more residue after burning in barbecue grills.

The energy densities (ED) were higher than the ones found in the literature for wood charcoal. COSTA et al. (2017) showed energy densities of around 11.15 GJ.m ${ }^{-3}$ when studying the household charcoal marketed in Cuiabá (MT), Brazil. Similarly, when studying the household charcoal marketed in Paraná, Brazil, OLIVEIRA et al. (2019) claimed that the highest ED among all the studied brands was 14.94 GJ.m ${ }^{-3}$.

The charcoal produced with briquettes made exclusively from Pinus spp. shavings presented the highest gross calorific value (GCV). The increase in the proportion of sludge in the blends caused a sequent reduction in the charcoal's GCV. Values lower than $28.47{\mathrm{MJ} . \mathrm{kg}^{-1}}^{1}$ represents charcoals with lower quality than those produced from wood, thus presenting low energy potential.

BRAND et al. (2015) reported an average

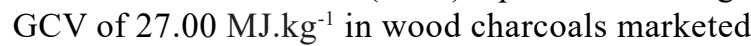
in South Brazil, which is lower than the GCVs of treatments T1, T2, T3, and T4. Conversely, ROSA et al. (2012) presented GCVs between 30.98 MJ.kg-1 and $32.65 \mathrm{MJ}^{-1} \mathrm{~kg}^{-1}$ when studying wood charcoal samples for household use, and NEVES et al. (2011) reported a mean GCV of $32.02 \mathrm{MJ} . \mathrm{kg}^{-1}$ in Eucalyptus spp. charcoals.

Regarding the energy density (ED), up to $70 \%$ of sludge in the blend had an evident influence on the reduction of the charcoal's ED with the increase of sludge proportion in the blend. However, blends containing $90 \%$ of sludge (T9) showed increased EDs, and they were statistically similar to treatments T1, T2, and T3. As shown in table 2 and figure 2, the high ED of the treatment T9 was due to the high charcoal's BD. Conversely, treatments T1, $\mathrm{T} 2$, and T3 presented high EDs because of the GCV and not the BD.

Pearson's correlation coefficient (r) may explain why T9 containing $90 \%$ of sludge presented an ED similar to treatments containing only up to $30 \%$. The $\mathrm{R}^{2}$ between the ED and the GCV was 0.56 , and between the $\mathrm{ED}$ and the $\mathrm{BD}$ was 0.19 . Both values are low, which represents that the relationship between the variables is not strong.

In the production process, the GY is the leading property. Our results were similar to the ones reported in the literature for wood charcoal. The CR is essential in the handling, and, as mentioned before, the charcoal produced with briquettes containing sludge presented adequate numbers. According to ROSA et al. (2012), the quality of the charcoal in its final use is linked to a high $\mathrm{ED}$, low $\mathrm{AC}$, and low VM.

Overall, results did not show a tendency to place only one treatment as the one which presented the best numbers in all the analyzed properties. The treatment $\mathrm{T} 7$ presented the best $\mathrm{GV}$ on its own.

Ciência Rural, v.51, n.12, 2021. 


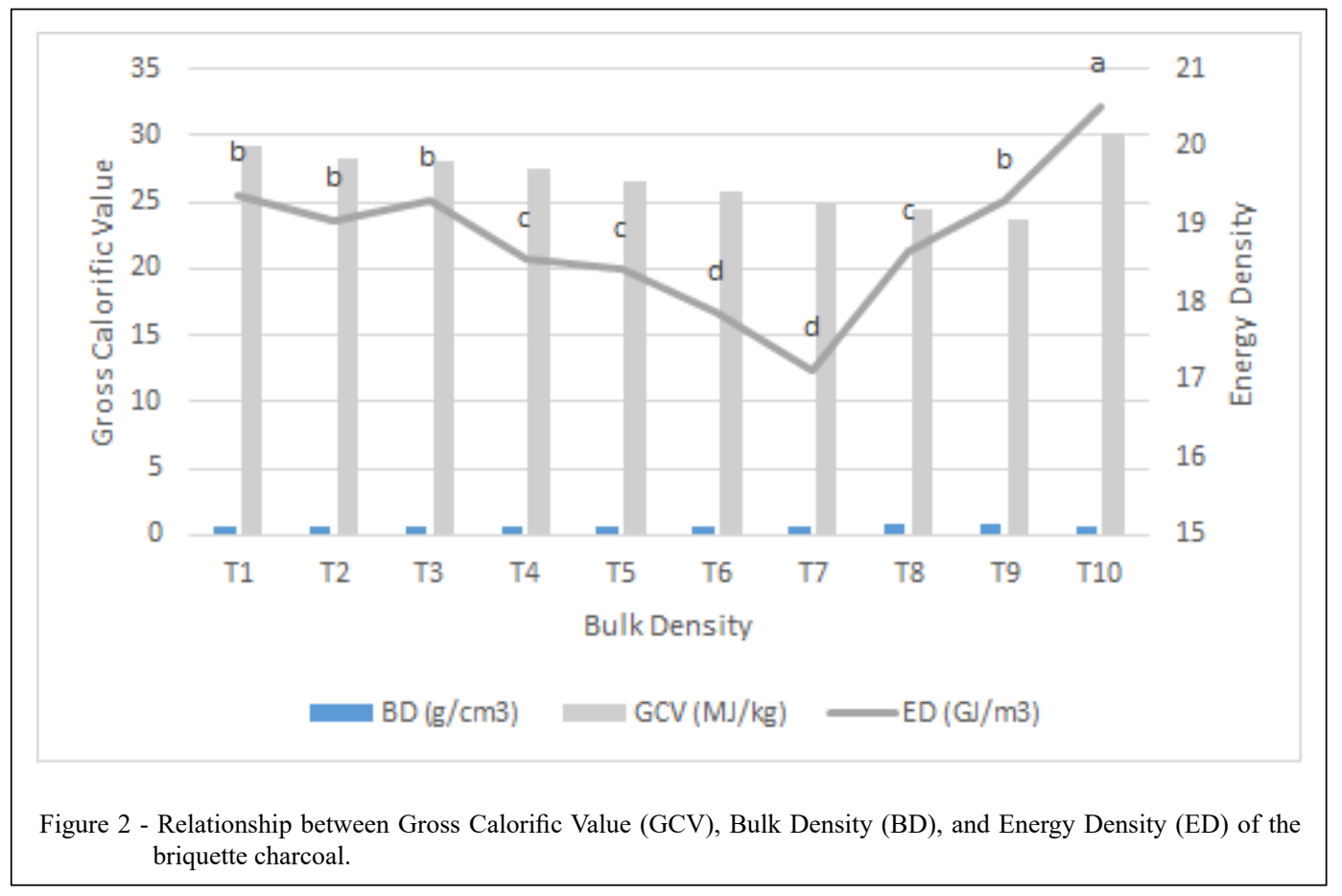

Treatments T1, T2, and T3 had the highest CRs. Treatment T9 showed the lowest VM, followed by $\mathrm{T} 5, \mathrm{~T} 6, \mathrm{~T} 7$, and $\mathrm{T} 8$, which were all statistically similar. Treatment $\mathrm{T} 1$ presented the best percentage of AC. Treatments T9, T1, T2, and T3 showed the highest EDs, all statistically similar.

However, we highlighted the treatment T9 as the one that resulted in the charcoal with the best characteristics for energy generation in household barbecue grills. It is among the treatments with the highest EDs, the lowest VM, and, even though it presented a lower GY than the other treatments, the numbers are similar to the ones found in the literature for wood charcoal. Moreover, the charcoals produced with T9 have the highest amount of sludge, and this study aimed to better optimize the use of this residue in charcoal production without harming the quality of the charcoal.

Besides, we would like to highlight that the composition of the sludge from poultry slaughterhouse wastewaters varies and; therefore, each sludge from different abattoirs must be tested individually before using it in charcoal production.

\section{CONCLUSION}

The different proportions of sludge in the blends used to produce the briquettes influence the charcoal's compressive resistance (CR), bulk density (BD), gross calorific value $(\mathrm{GCV})$, proximate analysis (VM, AC, and FC), and energy density (ED). It does not influence the charcoal's moisture content (MC) and the gravimetric yield (GV), however.

The compressive resistance (CR), the gross calorific value (GCV), the volatile matter (VM), and the fixed carbon content (FC) of the charcoals decreased by increasing the proportion of sludge in the blends. Conversely, the charcoal's bulk density (BD) increased with the addition of sludge in the blends, also increasing their energy density (ED) and ash content (AC).

Based on the results, considering the energy potential of the charcoal per volume unit, the low volatile matter (VM), and the amount of sludge in the blends, we highlight that the best blend to produce charcoal for household use was the one containing $90 \%$ of the sludge and $10 \%$ of Pinus spp. shavings (T9). Despite its high ash content (AC), as it only represents more residue after burning without energy losses.

\section{ACKNOWLEDGEMENTS}

We thank the Conselho Nacional de Desenvolvimento Científico e Tecnológico [grant numbers: CNPq - Case 303063/2017-3 - PQ - 2017], the Fundação de Amparo à Pesquisa e Inovação do Estado de Santa Catarina (FAPESC), the Coordenação 
de Aperfeiçoamento de Pessoal de Nível Superior (CAPES) and Gestão de Recursos Florestais and Qualidade e Utilização de Recursos Florestais e Ambientais Research Groups.

\section{DECLARATION OF CONFLICT OF INTEREST}

The authors declare no conflict of interest. The founding sponsors had no role in the design of the study; in the collection, analyses, or interpretation of data; in the writing of the manuscript, and in the decision to publish the results.

\section{AUTHORS' CONTRIBUTIONS}

All authors contributed equally for the conception and writing of the manuscript. All authors critically revised the manuscript and approved of the final version.

\section{REFERENCES}

ABPA. Associação Brasileira de Proteína Animal. Relatório Anual de Atividades 2019. São Paulo, 2019. Available from: $<$ http://cleandrodias.com.br/wp-content/uploads/2019/05/ RELATO\%C3\%ACRIO-ANUAL-ABPA-2019.pdf>. Accessed: Jan. 20, 2020.

BEUX, S. Avaliação do tratamento de efluente de abatedouro em digestores anaeróbios de duas fases. 2005. Dissertation (Post-degree in Food Science and Technology) - Universidade Estadual de Ponta Grossa, Ponta Grossa, 2005. Available from: $<$ http://livros01.livrosgratis.com.br/cp091760.pdf $>$. Accessed: Jun. 07, 2018.

BRAND, M. A. et al. Quality of charcoal for domestic consuption marketed in the southern highlands region of Santa Catarina. Revista Árvore, v.39(6), p.1165-1173, 2015. Available from: $<$ https://doi.org/10.1590/0100-67622015000600020>. Accessed: Oct. 10, 2019. doi: 10.1590/0100-67622015000600020.

BRAND, M. A. et al. Production of briquettes as a tool to optimize the use of waste from rice cultivation and industrial processing. Renewable Energy, v.111, p.116-123, 2017. Available from: $\quad<$ https://www.sciencedirect.com/science/article/abs/pii/ S0960148117302756?via\%3Dihub>. Accessed: Nov. 10, 2019. doi: 10.1016/j.renene.2017.03.084.

BRASIL. BEN: Balanço Energético Nacional 2016, ano base 2015. Brasília: Empresa de Pesquisa Energética, 2016. Available from: $<$ https://ben.epe.gov.br/downloads/Relatorio_Final_BEN_2016. pdf $>$. Accessed: Jul. 02, 2018.

BRASIL. Lei no. 12,305 , de 2 de agosto de 2010. Institui a Política Nacional de Resíduos Sólidos; altera a Lei no 9.605, de 12 de fevereiro de 1998; e dá outras providências. Diário Oficial [da] República Federativa do Brasil. Brasília, Aug. 2, 2010. Available from: <http://www.planalto.gov.br/ccivil 03/ ato2007010/2010/lei/112305.htm>. Accessed: Jul. 09, 2018.

BOTREL, M. C. G. et al. Genetic improvement of Eucalyptus charcoal properties. Revista Árvore, v.31(3), p.391-398, 2007. Available from: <https://doi.org/10.1590/S010067622007000300004>. Accessed: Dec. 09, 2019. doi: 10.1590/ S0100-67622007000300004.
COSTA, A. C. S. et al. Quality charcoal for cooking food marketed in Cuiabá city - MT, Brazil. Sinop: Nativa, v.5, n.6, p.456-461, 2017. Available from: <https://www.researchgate.net/ publication/326492433_Qualidade_do_carvao_vegetal_para_ coccao de alimentos comercializado em Cuiaba - MT>. Accessed: Oct. 17, 2019. doi: 10.5935/2318-7670.v05n06 $\overline{\mathrm{a}} 12$.

DE LUCAS J. R.; SANTOS, T.M.B. Aproveitamento de resíduos da indústria avícola para produção de biogás. In: SIMPÓSIO SOBRE RESÍDUOS DA PRODUÇÃO AVÍCOLA. Anais..., Concórdia, SC, p.27-43, 2016. Available from: $<$ http://docsagencia.cnptia.embrapa. br/suino/anais/anais65_lucas.pdf $>$. Accessed: May, 16, 2018.

FURTADO, T. S. et al. Variables of briquetting process and quality of forestry biomass briquettes. Pesquisa Florestal Brasileira, v.30, n.62, p.101, 2010. Available from: <https://www.researchgate. net/publication/296337926_Variaveis_do_processo_de briquetagem e qualidade de briquetes de biomassa florestal $>$. Accessed: Jul. 13, 2019. doi: $\overline{10} .4336 / 2010 . \overline{p f b} .30 .62 .101$.

GARCIA, N.N. Uso do lodo de flotador de abatedouro de aves na produção de biochar. Trabalho de Conclusão de Curso Universidade Tecnológica Federal do Paraná, 2016. Available from: $<$ http://repositorio.roca.utfpr.edu.br/jspui/bitstream/1/5072/1/CM COEAM_2016_1_15.pdf>. Accessed: Jun. 10, 2019.

GRANADA, E. et al. Fuel lignocellulosic briquettes, die design and products study. Renewable energy, v. 27, n. 4, p. 561-573, 2002. Available from: <https://doi.org/10.1016/S0960-1481(02)00005-8>. Accessed: Aug. 12, 2019. doi: 10.1016/S0960-1481(02)00005-8.

NASCIMENTO, A. H. et al. Chemical composition and metabolizable energy values of feathers meal and poultry by-product meal determined by different methodologies for chickens. R. Bras. Zootec, p.1409-1417, 2002. Available from: $<$ https://doi.org/10.1590/S151635982002000600012>. Accessed: Nov. 23, 2020.

NONES, D. L. et al. Determination of energetic properties of wood and charcoal produced from Eucalyptus benthamii. Floresta, v.45, n.1, p.57-64, 2014. Available from: <http://dx.doi.org/10.5380/ rf.v45i1.30157>. Accessed: Sept. 21, 2019. doi: 10.5380/ rf.v45i1.30157.

OLIVEIRA, A. F. et al. Charcoal quality analysis for domestic consumption of four municipalities in the state of Paraná. Revista Brasileira de Energias Renováveis, v.4(3), 2015. Available from: $<$ http://dx.doi.org/10.5380/rber.v4i3.43034>. Accessed: Aug. 10, 2019. doi: $10.5380 /$ rber.v4i3.43034.

OLIVEIRA, R. S. et al. Quality of charcoal marketed in southeast Pará for cooking foods. Amazonian Journal of Agricultural and Environmental Sciences, v.62, 2019. Available from: $<$ https://www. researchgate.net/publication/326492433_Qualidade_do_carvao_ vegetal_para_coccao_de_alimentos_comercializado_em_Cuiaba_MT>. Accessed: Dec. 5, 2019. doi: 10.5935/2318-7670.v05n06a12.

PINTO, L. A. M. et al. Torrefaction of wood. Part 2. Analysis of products. Journal of Analytical and Applied Pyrolysis, v.77, p.35-40, 2006. Available from: <https://doi.org/10.1016/j. jaap.2006.01.001>. Accessed: Sept. 23, 2019. doi: 10.1016/j. jaap.2006.01.001.

PNUD. United Nations' Development Program. Transforming Our World: The Agenda 2030 for Sustainable Development. 2015. Available from: <http://www.pnud.org.br/Docs/ Agenda2030completo_PtBR.pdf>.Accessed: Nov. 16, 2019. 
PRINS, M. J.; et al., Torrefaction of wood. Part 2. Analysis of products. Journal of Analytical and Applied Pyrolysis, v.77, p.35-40, 2006 Available from: <https://doi.org/10.1016/j.jaap.2006.01.001.>. Accessed: May, 16, 2019. doi: 10.1016/j.jaap.2006.01.001.

PROTÁSIO, T. P. et al. Steel and energetic potential of charcoal of Eucalyptus spp. clones at 42 months of age. Pesquisa Florestal Brasileira, v.33(74), p.137-149, 2013. Available from: <https:// doi.org/10.4336/2013.pfb.33.74.448>. Accessed: Nov. 28, 2019. doi: $10.4336 / 2013 . p f b .33 .74 .448$

ROSA, R. A. et al. Quality of charcoal for domestic consumption. Journal of Biotechnology and Biodiversity, v.3, n.2, p.41-48, 2012 Available from: <https://doi.org/10.20873/jbb.uft.cemaf.v3n2.rosa $>$. Accessed: May, 20, 2019. doi: 10.20873/jbb.uft.cemaf.v3n2.rosa.

SANTOS, M. A. S. Parâmetros de qualidade do carvão vegetal para uso em alto-forno. In: FÓRUM NACIONAL SOBRE CARVÃO VEGETAL, 1., 2008, Belo Horizonte. Anais... Belo Horizonte: UFMG, 2008. 1 CD-ROM.
SÃO PAULO. Secretaria de Agricultura e Abastecimento. Resolução no 40 SAA. São Paulo, 2015. Available from: <https:// www.defesa.agricultura.sp.gov.br/legislacoes/resolucao-saa-40de-24-08-2018,1177.html>. Accessed: Feb. 10, 2019.

TOLMASQUIM, M. T. Geração de energia elétrica no Brasil. Rio de Janeiro: Interciência, 2005.

UNFRIED, L. C.; YOSHI, C.V.H. Sustentabilidade No Abate E Processamento De Aves. Revista FACESI, v.4, special edition, 2012. Available from: <https://docplayer.com.br/14379729Sustentabilidade-no-abate-e-processamento-de-aves.html>. Accessed: Oct. 23, 2019.

VEIGA, T. R. L. A. et al. Effect of the sample length in compressive strength of Eucalyptus wood and charcoal. Pesquisa Florestal Brasileira, v.36(88), p.399-403, 2016. 10, 2019. Available from: $\quad<$ https://pfb.cnpf.embrapa.br/pfb/index.php/pfb/article/ view/1073/532>. Accessed: Jun. 03, 2019. doi: 10.1111/j.1744697X.2007.00072.x. 